UDK 821.111(73)-311.2.09 Toole J.K.

\title{
FEAST OF FOOLS: THE CARNIVALESQUE IN JOHN KENNEDY TOOLE'S A CONFEDERACY OF DUNCES
}

\author{
Julija Potrč
}

\begin{abstract}
Despite the fact that the action in John Kennedy Toole's novel A Confederacy of Dunces has often been compared to a carnival, there is little that the main character, Ignatius Reilly, has in common with those participating in a true medieval carnival as described by Mikhail Bakhtin in Rabelais and His World. Ignatius tries to assert his superiority over others both with his speech and behavior, violating the principal rule of carnivalesque equality, and is aggressively opposed to sexuality, which was a deeply positive concept in the carnival culture, symbolizing fertility, growth, and new birth. A great source of humor in the novel is the difference between the highly educated speech used by Ignatius and the vernacular spoken by other characters. This difference was successfully transposed into Slovene by translator Nuša Rozman, who managed to capture the differences between social classes by using various degrees of colloquialisms and slang expressions, while opting to nevertheless transcribe the characters' speech in a way that is grammatically correct; a practice that has long been present in both original and translated Slovene literature, which highlights the fact that despite an increase in the number of works written in the vernacular over the past years, a universal standard on how to transcribe spoken Slovene has yet to be established.
\end{abstract}

Key words: Carnival, folk humor, carnivalesque langhter, New Orleans vernacular, literary translation

Unknown until 1980, when his comic masterpiece A Confederacy of Dunces was published after waiting for a publisher for over a decade and a half, John Kennedy Toole (1937-1969) attained recognition by being posthumously awarded the Pulitzer Prize the year following the novel's publication, and is now recognized as the author of one of America's "most widely read southern novels" (Haddox 2005: 168). Due to his premature death by suicide at the age of thirty-one, Toole never wrote anything after having completed his most celebrated work. In fact, he wrote his only other novel, The Neon Bible, at the age of sixteen and considered it too juvenile for publication during his lifetime, although the work was eventually published following the success of Confederacy, and even made into a feature film. However, it is the Pulitzer Prizewinning novel, borrowing its title from a quotation by Jonathan Swift in his Thoughts on Various Subjects, Moral and Diverting, which has attracted most attention from 
both readers and critics, and which, according to Nevils, had 1.5 million copies in print by 2001 (214).

Set in New Orleans, the novel follows the adventures of one Ignatius Reilly, a misfit and slob of colossal proportions, who at the age of thirty is forced by his alcoholprone mother to leave the sanctuary of his room for the first time. Ignatius is a true anti-hero who would prefer to be scribbling a denouncement of the modern world and praising the orderliness of the Middle Ages to finding a job and assuming an active role in the society he has been so busily condemning - which is exactly what he is forced to do following his mother's car accident and the ensuing law suit. Unequipped as he is with the social skills required to function normally in everyday situations, Ignatius is whisked from one disaster to another and finds himself in situations which are at the same time both hilarious and sad. While taking up a series of low-paid jobs, first as a clerical worker in a disreputable pants factory and finally as a street vendor selling hot dogs, he crosses paths with an impressively wide array of characters of all ages, social positions, and professions, who together form a rich collage of life in New Orleans in the 1960s.

The very fact that the novel is set in New Orleans, a city widely known for its Mardi Gras celebrations, combined with the humorous tone of the book, the bizarre mishaps and misadventures of the main character, and the general tendency of the characters to be clad in costumes, naturally brings to mind the carnival as an appropriate term embodying the spirit of the work. Such descriptions of the plot as "a carnival of modern life" epitomized by "a krewe of Mardi Gras dunces" are therefore quite common when discussing the novel, both in academic and more general circles ${ }^{1}$ (Simon 1994: 99). Critics are correct to stress the predominately carnivalesque aspect of this work, but, as we shall see, the world of Ignatius Reilly is only similar to a carnival on the surface; at its core it remains fundamentally different from the true carnival culture of the Middle Ages.

In his seminal work Rabelais and His World, Mikhail Bakhtin discusses the concepts of folk humor, carnival culture, and grotesque realism by drawing heavily on François Rabelais' sixteenth-century tales of two giants, Gargantua and Pantagruel. In fact he goes as far as to call Rabelais' novel "the most festive work in world literature" (275). Rabelais was still very much in touch with the spirit of the carnival as an event implying freedom and festivity, in line with the long-standing carnival tradition in the area of Southern France where the writer lived, and his work therefore represents "perhaps the purest form of carnivalesque literature" (Horton 1999: 56). If the sixteenth century was truly "the summit in the history of laughter", as Bakhtin claims, it becomes necessary to evaluate the carnivalesque in Toole's work against the yardstick of the medieval carnival, complete with its festive activities, the concept of universal laughter, and the language of the marketplace (101).

According to Bakhtin, the carnival "celebrated temporary liberation from the prevailing truth and from the established order" (10). The strict hierarchical organiza-

\footnotetext{
${ }^{1}$ See Julian Gough's essay "Divine Comedy," published in the May 2007 issue of the magazine Prospect, and Walker Percy's foreword to John Kennedy Toole's A Confederacy of Dunces (1980; repr., London: Penguin Books Ltd, 1995), v-vii, where the terms "commedia" and "gargantuan /.../ tragicomedy" are used to typify the work.
} 
tion of society in the Middle Ages meant that people were well aware of the social caste they belonged to and the strict rules governing such that they had to conform to. Throughout most of the year they lived in fear of authority and were weighed down by constant prohibitions and limitations. In order for such a system to remain sustainable, there had to be certain periods in the year when the barriers of social class were let down and free laughter reigned - these periods were feasts and the carnival. It was almost as if people in the Middle Ages had two separate lives: normal life and carnival life, and as if two aspects of the world existed side by side in their minds, that of seriousness and of laughter (Bakhtin 1984: 96).

In Confederacy, the normal existential mode of the main character is idleness, a state completely devoid of any rules and prohibitions and one in which he feels comfortable. Ironically, Ignatius sees the Middle Ages as a period when western man enjoyed "order, tranquility, unity and oneness with its True God" and blames the moral degradation (as he sees it) of the modern world on the loss of these ideals (Toole 1995: $25)$. The very order for which Ignatius longs is one in which he is unable to function, as even such a relatively simple task as finding a low-paid job and keeping it proves too much of a challenge. Having been forced by his mother to leave the confines of his room, Ignatius is thrust into the unsuspecting world and left with no other option but to join the carnival of life around him.

Owing to his uncouth appearance, his haughty and often abusive attitude to those around him, and his sophisticated speech, Ignatius is soon labeled a madman. Darlene, an employee at a strip club, the Night of Joy, is quick to point out that Ignatius looks like "a big crazyman" (20). Jones, the black, underpaid porter at the same night club, characterizes Ignatius as "one-hunner-percen freak" and adds that he "sound like a crazy white mother" when talking to one of his friends who works at Levy Pants, where Ignatius is getting ready to spark a revolution (115). A similar reaction is heard from a group of ladies exhibiting their still life paintings, which Ignatius, dressed in his hot dog vendor regalia, mercilessly criticizes: "He's mad. He's so common. So coarse" (210). Similarly as the clowns and fools of the Middle Ages, who were not just actors playing their parts on the stage, but retained their role at all times and wherever they went, Ignatius also seems to trigger the same reaction wherever he goes; but unlike the clowns who provoked laughter, Ignatius only provokes scorn and contempt. The society does not embrace him, but views him as an unwanted element, one which is causing trouble and needs to be eliminated.

The greatest problem for Ignatius and the reason why others find it difficult, if not outright impossible, to accept him, is the fact that he perceives himself to be superior to others, and in doing so violates the fundamental principle of carnivalesque equality. In fact, nothing could be further from the true spirit of the medieval carnival. According to Bakhtin, whoever is addressing the crowd during a carnival "is one with the crowd; he does not present himself as its opponent, nor does he teach, accuse or intimidate it" (167). Ignatius does all of these things. When talking to the ladies exhibiting their paintings, he first accuses them of knowing nothing of art: "You women had better stop giving teas and brunches and settle down to the business of learning how to draw," and then tries to impress on them that they "need a course in botany. And perhaps geometry, too" (210). He frequently takes on a hostile and aggressive attitude, as he does 
with Myrna Minkoff, his old college acquaintance, whom he characterizes as "a loud, offensive maiden from the Bronx" and in every letter sent by her claims to find "some reference to the sleaziness of [her] personal life" $(107,157)$. Mockery in Toole's work is not universal, it is derisive and expresses contempt. In medieval folk culture, praise was ironic and ambivalent, it was always on the brink of abuse and vice versa, so much so that it "was impossible to draw the line between them" (Bakhtin 1984: 165). There is nothing ambivalent in Ignatius' abusive remarks; they are meant to establish his superiority and show others how inferior they are.

The humor of the work therefore does not stem from the characters' awareness of their position in the world and from their ability to accept this position and adopt a carefree attitude towards it, as was the case with those participating in a medieval carnival. According to Bakhtin, carnivalesque laughter was "directed at the whole world, at history, at all societies, at ideology" (84). Further on, the culture of folk humor embraced all people and belonged to everybody; laughter was irresistible and could not be confined. In fact, the laughter of the carnival was so powerful that it completely overcame the fear instilled by the authoritarian figures; it was a true "victory of laughter over fear" (Bakhtin 1984: 90). This is far removed from the many embarrassing situations in which Ignatius either insults or criticizes others, situations that do not bring a smile to his face, and much less to the faces of his interlocutors. Indeed, instead of reveling in his adventures, Ignatius tries at every step to establish his authority and superiority. The only party able to laugh is the reader, who is acutely aware of the breach between the image of himself that Ignatius maintains, that of an intellectually superior human being who is perpetually right, and the way in which he is perceived by everyone elsean arrogant and pitiful lunatic.

The many inconsistencies between what Ignatius proclaims to be his ideals and his actual words and actions are quite striking, and also a superb source of humor. McNeil goes so far as to claim that Ignatius "epitomizes the very perversions against which he rages" (35). While he proclaims himself to be "the avenging sword of taste and decency", Ignatius is actually the one who walks around dressed like "a performer of some sort", in his green cap, lumber jacket, and suede boots, and his personal hygiene standards are so low that he receives a complaint from the Board of Health a few days after assuming a job as a hot dog vendor (Toole 1995: 213, 17). Moreover, while raging against the perversions and excesses of the modern age and advocating medieval asceticism, he obviously does not see it unfit to wolf down boxes of wine cakes and guzzle enormous quantities of Dr. Nut, his favorite drink. The same holds true for his moral standards: as Ruppersburg noted, Ignatius is exactly the opposite of the moral superiority he preaches (119). His motives are usually selfish and he can only think about how a certain action is going to affect him without considering other people - on a whim, he writes an offensive letter to a business associate of Levy Pants, which results in a law suit and jeopardizes the existence of the company and the jobs of its employees. In short, Ignatius behaves like a spoiled child.

However, it is difficult to perceive Ignatius in an entirely negative light. Despite often behaving in an arrogant and obnoxious manner, there is something about him which also makes him pitiful. With all his education, including a Master's degree, Ignatius is still living with his mother in a small, run-down house in a suburb of New Orleans at 
the age of thirty. He obviously does not have any friends, with the exception of Myrna Minkoff, and even she remains absent until the very end of the novel, when she appears in a deus ex machina fashion and whisks her college friend away to New York. Ignatius' superiority is merely a defense mechanism, the only way he knows how to cope with reality and to maintain a relatively respectable self-image. After all, he is convinced that it cannot be his fault that the world fails to recognize his brilliance and that, as a result, he is unable to find suitable employment. It is the fault of everyone else, of the dunces who are in a confederacy against him.

At least part of Ignatius' problem seems to be that he is over-educated, a fact which feeds his feelings of superiority and alienates him from the people around him. This is well noted by George, a truant teenager running shady errands for the proprietress of the Night of Joy, in describing Ignatius: "You could tell by the way that he talked, though, that he had gone to school a long time. That was probably what was wrong with him. George had been wise enough to get out of school as soon as possible. He didn't want to end up like that guy" (243-244). The same idea is also expressed by Mr. Robichaux, the elderly suitor of Mrs. Reilly: "Maybe your boy went to school too long" (175). In the Middle Ages, the representatives of institutions such as the church or the university system embodied authority and absolute truths. They took themselves very seriously and refused to laugh, considering all those who opposed them to be enemies of the eternal truth. Of course, this attitude is completely out of keeping with the carnivalesque spirit of equality and relativity. The main message of the carnival is that there are no eternal and divine truths, that the old order must always die to make way for a new, better order. However, these officials "do not see themselves in the mirror of time, do not perceive their own origin, limitations and end" (Bakhtin 1984: 213). Ignatius is just such a defender of scholastic truths, insisting that everyone should treat him with due reverence simply based on the fact that he personifies the old, established traditions exemplified by the university, and in doing so fails to see his own transience and the transience of the truths he is defending. By not being able to laugh at himself, he actually becomes the dunce he accuses everyone else of being.

Relativity was an especially important aspect of the carnival. For a brief time the differences between superiors and inferiors were eliminated and all hierarchies were cancelled, all classes and ages were equal. Bakhtin further points out that the very essence of the carnival was not "in the subjective awareness but in the collective consciousness of [the people's] eternity, of their earthly, historic immortality as a people" (250). An individual's fate was unimportant, it was the people or the crowd as a whole that mattered. When a person embraces the fact that he is just a minute element in the constant cycle of rebirth and regeneration, his own life is put into perspective and he becomes aware that he can take himself lightly, because ultimately an individual does not matter, it is the people collectively who matter. Ignatius is incapable of perceiving himself in this way. His everyday worries and frustrations occupy him so much that he is unable to see beyond them, unable to comprehend the laughable minuteness of his own existence and the relative unimportance of his life. The only relativity he does grasp is that of the upwards and downwards cycles of his own fate. True to his medievalist background, Ignatius believes "that a blind goddess spins us on a wheel" and that "our luck comes in cycles" (27). Upon finding out that he would have to get a job to pay off 
the law suit following his mother's car accident, he reflects: "Oh, what low joke was Fortuna playing on him now? Arrest, accident, job. Where would this dreadful cycle ever end?" (42). Despite acknowledging that he is for the present moment caught in a bad cycle which will sooner or later pass and be replaced by a good cycle, Ignatius is incapable of recognizing the relative insignificance of the events which befall him in the spirit of folk culture and humor.

The carnivalesque relativity and ambivalence are also reflected on other levels. Much like praise has always been ambivalent and on the brink of abuse, so a genius has always been on the brink of becoming a fool. Indeed, there is a thin line between genius and insanity. Ignatius is so well educated that he considers himself to be a genius, while other people consider him mad. Bakhtin explains that one of the basic elements of folk culture was the reversal of hierarchic roles - at a carnival the jester was proclaimed king and "a clownish abbot, bishop, or archbishop was elected" (81). The reversal of roles is in fact an example of degradation, but degradation in this case does not mean something negative; on the contrary, it is a chance for rebirth, for a new beginning. The participants at a medieval carnival were aware that in order for something new to be born, something old must die. The decrowning of a king was therefore a joyous event, and even the person who was degraded or dethroned had no other option but to laugh along, embracing the universal spirit of regeneration. Ignatius, of course, fails to see this ambivalence and stubbornly persists in his role of a learned scholar, he refuses to cast his scholarly gown aside and become a part of the crowd. Until the very end, Ignatius takes himself and his role in life seriously.

Degradation also refers to the bodily level and should be taken quite literally, according to Bakhtin. It means coming down to earth; and earth is the element which swallows up and gives birth at the same time. But to degrade also means to deal with the lower stratum of the body, relating to acts of defecation, copulation, conception, pregnancy, and birth. The destructive principle is closely followed by the regenerative one (21). The carnivalesque body is always exaggerated. The same seems to hold true for Ignatius. His body is not only physically exaggerated because of his obesity; there is also a great deal of talk about various bodily functions because of his preoccupation with his body. Ignatius explains his health problems to anyone who will listen, including his employer at Paradise Vendors, Mr. Clyde. "My digestive system has almost ceased functioning altogether. Some tissue has perhaps grown over my pyloric valve, sealing it forever," he tells him (181). Ignatius exaggerates any health problem just to convince his listener of his suffering. When walking down the street he complains to his mother, "Will you please slow down a bit? I think I'm having a heart murmur." (7) However, in this case the body is presented as a single, self-sufficient entity and whatever happens within it concerns it alone; it is not the grotesque body of the carnival, which is "cosmic and universal", constantly being renewed and never finished (Bakhtin 1984: 318). For the grotesque body, disease and death represented a chance for a new birth, but in the case of Ignatius this universal and positive aspect is lost—his health problems only pose a threat and danger.

Ignatius does not think only about his health, he also constantly thinks about food. One of the first scenes of the book features Mrs. Reilly buying cakes for her son at a department store. And when working as a hot dog vendor some years later, 
he manages to consume most of the products himself, which ultimately leads to his weight increasing even more and, of course, the dissatisfaction of his employer. Bakhtin stresses that feasting was part of every folk carnival and that it was included in all comic scenes. However, folk feasting in the Middle Ages was "a banquet for all the world in which all take part", it was not confined to the house or to private rooms, but instead happened in a public place such as the marketplace (302). Moreover, feasting was a joyful and triumphant event, it was an occasion where man "triumphs over the world, devours it without being devoured himself" (Bakhtin 1984: 281). There is nothing particularly joyful and triumphant in the way Ignatius devours two dozen jelly doughnuts, such that the cake box looks "as if it had been subjected to unusual abuse during someone's attempt to take all of the doughnuts at once" (Toole 1995: 35). Ignatius' bingeing sessions have nothing in common with the universal and merry character of medieval feasts; in fact, there is something infinitely sad about them, as Ignatius gorges on food in a futile attempt to overcome his loneliness, sadness, and sexual frustration.

Excessive eating also causes him to display other bodily actions such as belching and emitting gas. One such incident takes place when Ignatius offers hot dogs to ladies exhibiting their artworks and manages to belch violently during the uncomfortable silence that follows. When it suits him, Ignatius claims in a medieval spirit that the body with all its smells and sounds is something completely natural, responding to his mother when she is appalled by the smell of his room: "Well, what do you expect? The human body, when confined, produces certain odors which we tend to forget in this age of deodorants and other perversions" (41). Even Bakhtin tells us that images of food and drink are closely related to those of the grotesque body and procreation (279). However, this is yet another inconsistency between Ignatius' words and deeds-in reality he is terrified of any physical contact and nothing scares him more than sexuality. This is completely out of keeping with the sexual role of the body in carnival culture, where sexuality represents fertility, growth, and new birth. During the carnival, the sexual aspects of the body must not be hidden and concealed but rather emphasized and honored. Ignatius cannot even stand the thought of touching another person, much less engaging in sex. When his mother informs him that her elbow has to be massaged because of her arthritis, Ignatius replies, "I hope you don't want me to do that. You know how I feel about touching other people" (9). Later Mrs. Reilly suggests that her son should settle down with Myrna and have a baby or two, and Ignatius tells her, "Do I believe that such obscenity and filth is coming from the lips of my own mother?" (46). In failing to embrace sexuality, Ignatius fails to appreciate the very cornerstone of folk culture: regeneration, new birth, and growth.

Finally, we have to discuss perhaps the single greatest source of humor in Confederacy: the language spoken by the different characters. Toole was a master of reproducing local speech with all its colloquialisms and registers, ranging from the lingo of the black porter Jones, to the New Orleans dialect represented by Mrs. Reilly and her friend Santa Battaglia. In sharp contrast to them all is the academic and highly stylized speech of Ignatius. His manner of speaking is so grandiose that others often have a hard time understanding him. When organizing a protest rally at the Levy Pants factory, the black workers do not quite follow Ignatius' address: 
"Friends! /.../ At last the day is ours. I hope that you have all remembered to bring your engines of war." From the group around the cutting table there issued neither confirmation nor denial. "I mean the sticks and chains and clubs and so forth." Giggling in chorus, the workers waved some fence posts, broomsticks, bicycle chains, and bricks. "My God! You have really assembled a rather formidable and diffuse armory." (118)

By maintaining a formal distance with his educated manner of speech, Ignatius once again asserts his superiority and places himself above his interlocutors. Such an attitude goes against the type of communication established during the period of the carnival, which was based on familiarity and permitted two people who had established friendly relations to address each other informally, and use abuses and mockery affectionately (Bakhtin 1984: 16). There is nothing affectionate about the abuses Ignatius unleashes on those around him; on the contrary, he does his best to not become friendly and familiar with others.

The many different variations of New Orleans vernacular as spoken by the characters from different social backgrounds undoubtedly prove to be one of the greatest challenges also for translators. The Slovene translation of Toole's novel was published in 2007, twenty-seven years after Confederacy was first published in the USA, and joins a long list of translations of the novel into other languages ${ }^{2}$. It seems almost impossible to capture all the intricate nuances of the New Orleans dialect spoken by the characters from different ethnic groups (for example the black porter Jones and the Latino waitress selling drinks during the last episode in the Night of Joy) and from different social classes (the speech of upper-middle class Levys differs from the speech of lower-middle class whites, such as Patrolman Mancuso and Santa Battaglia). For historic reasons and due to Slovenia's relatively mono-ethnic situation, it is hard to transpose the dialects spoken by ethnic groups and social classes in New Orleans into Slovene. Of course, different dialects could be used, but it would seem inappropriate to assign the various characters different Slovene dialects, for example the dialect of the Gorenjska, Primorska, and Štajerska regions, not only because Confederacy has a strong local character and all the people in it come from one city, but also because such a decision would leave readers wondering what characters from different regions of Slovenia were doing in New Orleans in the 1960s. There is also the problem of translating Ignatius' academic diction, because in Slovene, despite the many foreignisms that normally permeate academic and scientific papers, the distinction between general written language and the language used by scholars and scientists is not as pronounced as in English, where numerous words of Latin origin can be effectively used to create the effect of scholarly discourse.

Translator Nuša Rozman solved these challenges well and introduced several effective solutions. She chose the neutral, written language as the basis of the translation (the characters do not speak any particular Slovene dialect), and sprinkled it with colloquial and informal expressions to an appropriate degree, depending on the speaker. For example, Mrs. Reilly and her friend Santa Battaglia, representatives of

\footnotetext{
${ }^{2}$ See the biography written by Nevils, René Pol, and Deborah George Hardy Ignatius Rising: The Life of John Kennedy Toole (Baton Rouge: Louisiana State UP, 2001), which states that translation rights have been sold in twenty countries.
} 
the lower-middle class of whites, speak a relatively neutral language in which indices such as short infinitive forms and spoken words are used every now and then to point to the unofficial character of their speech. On the other hand, the language of Jones, the black porter, includes more slang words, curse words, and expressions that could be characterized as 'low colloquial', emphasizing the fact that he comes from a lower social class. However, in keeping with an established tradition in Slovene translated literature ${ }^{3}$, Jones' speech (for all its slang expressions and colloquial nature) is still written is a way that is grammatically correct - that is, the spelling is correct and the words are not contracted to reflect how characters from a lower social class truly speak, as is the case in Toole's novel. Here is an example of Santa Battaglia's speech in the original and in Slovene translation:

"Don't be ashamed, babe. It ain't your fault you've got a brat on your hands," Santa grunted. "What you need is a man in that house, girl, to set that boy straight. I'm gonna find that nice old man ast about you." (150)

"Nič naj ti ne bo nerodno, mila moja. Saj nisi sama kriva, če imaš razvajenega otročeta na skrbi. Ti rabiš moškega pri bajti, punca, da bo spravil v red tega poba. Našla bom tistega prijetnega starega gospoda, ki je spraševal zate." (231)

Alongside the established contractions used to transcribe spoken English, such as 'ain't' and 'gonna', Toole also uses omissions ("nice old man [who] ast about you") and introduces new contractions ('ast' instead of 'asked') in order to remain as true to the characters' vernacular as possible. While the Slovene translator opted for a perfectly valid and effective solution by using selected jocular and colloquial expressions ('otroče' and 'pob' for 'brat' and 'boy', respectively, and the word 'bajta', a colloquial expression for 'house') to reflect the overall tone of the text, the other option would be to attempt transcribing contracted forms, for example 'nč' for 'nič' and 'maš' for 'imaš', or forms that would otherwise reflect the vernacular used ('sej' for 'saj', 'spravu u red' for 'spravil $\mathrm{v}$ red', etc.) This becomes even more critical in Jones' speech:

"Since we cuttin off the orphan chariddy and we not extendin it to the porter help, maybe we oughta give a little to a po, strugglin gal gotta hustle on commission. Hey!" (147)

"Če smo že nehali dajat vbogajme sirotam, ne da bi na ta račun malo pomagali čistilcu, bi mogoče lahko kaj padlo ubogi punci na začetku kariere, ki mora gurat za procente, mater duš!" (226)

As can be seen from the above quotation, Jones' speech is very colloquial indeed. There is a marked difference in register between the original and the Slovene translation, with the former abounding in colloquial expressions, contracted words and omissionsalmost every word is transcribed to reflect the actual vernacular of the black porter-and the latter predominately using standard literary language with some colloquial expres-

\footnotetext{
${ }^{3}$ See, for example, the translation of William Faulkner's short story "That Evening Sun" (Beseda, 1952/53), in which the black southern dialect of the character Nancy was translated into neutral, grammatically correct Slovene with occasional colloquial expressions.
} 
sions ('gurat' for 'hustle' and 'mater duš!', an exclamation used to substitute 'Hey!'). Unlike with Santa Battaglia, where the vernacular is not as pronounced, translation of Jones' speech would benefit from using selected contracted words.

More radical attempts to transcribe real spoken language in original Slovene literature have appeared more frequently during the last decade or $\mathrm{so}^{4}$, but translators still seem to be hesitant about transcribing the vernacular in a way that would reflect the actual speech. In order to contrast the speech of such characters as Jones and Battaglia with the highly educated language spoken by Ignatius, Nuša Rozman has used literary expressions and foreignisms, but the difference between the general language of the narration and Ignatius' stylized speech is not as pronounced as it is in the English original, which is mainly due to the previously mentioned characteristics of written Slovene. Nevertheless, the translation captures the different registers, and, most importantly, retains the humor originating from the language used in the original text.

Ljubljana, Slovenia

\section{WORKS CITED}

Bakhtin, Mikhail. Rabelais and His World. Trans. Hélène Iswolsky. Bloomington: Indiana UP, 1984.

Haddox, Thomas F. Fears and Fascinations: Representing Catholicism in the American South. New York: Fordham UP, 2005.

Horton, Andrew. Laughing Out Loud: Writing the Comedy-Centered Screenplay. Berkeley: U of California P, 1999.

McNeil, David. "A Confederacy of Dunces as Reverse Satire: The American Subgenre.” Mississippi Quarterly 38.1 (1984-1985): 33-47.

Nevils, René Pol and Deborah George Hardy. Ignatius Rising. The Life of John Kennedy Toole. Baton Rouge: Louisiana State UP, 2001.

Ruppersburg, Hugh. "The South and John Kennedy Toole's A Confederacy of Dunces." Studies in American Humor 5.2-3 (1986): 118-126.

Simon, Richard Keller. "John Kennedy Toole and Walker Percy: Fiction and Repetition in A Confederacy of Dunces." Texas Studies in Literature and Language 36.1 (1994): 99-116.

Toole, John Kennedy. A Confederacy of Dunces. 1980. London: Penguin Books Ltd, 1995.

\footnotetext{
${ }^{4}$ See the novel Fužinski bluz by Andrej Skubic (Ljubljana: Študentska založba, 2001) and, most recently, the best-seller Čefurji raus! by Goran Vojnović (Ljubljana: Študentska založba, 2008).
} 